\title{
Polyphenols contribute to the antioxidant and antiproliferative activity of Phyllanthus debilis plant in-vitro
}

\author{
Dananjaya Perera ${ }^{1}$, Preethi Soysa ${ }^{1 *}$ and Sumedha Wijeratne ${ }^{2}$
}

\begin{abstract}
Background: Phyllanthus debilis (Elapitawakka) is a medicinal plant used in traditional systems of medicine in Sri Lanka. Present study was carried out to evaluate in-vitro anti-oxidant and anti-proliferative activity of the water extracts of aerial parts (AP) and roots (RP) of P.debilis plant and the role of polyphenolic compounds in view of its medicinal use.
\end{abstract}

Method: Total polyphenols, flavonoids and proanthocyanidin content of the extracts were quantified. DPPH, hydroxyl radical, nitric oxide and hydrogen peroxide scavenging potentials and the total antioxidant capacity, ferric ion reducing power were determined to evaluate antioxidant capacity. Anti-proliferative activity was assessed with MTT assay for Human Rhabdomyosarcoma (RD) and normal rat liver cells (CC1) after $24 \mathrm{~h}$ exposure to the plant extracts. DPPH and MTT assays were carried out for AP and RP extracts after removal of polyphenols to assess the contribution of polyphenols on antioxidant and anti-proliferative activity of Phyllanthus debilis.

Results: Flavonoid content of the AP extract was significantly lower than that of RP $(P<0.001)$ while no significant difference was observed in polyphenolic as well as in proanthocyanidin contents. All the assays except for phosphomolybdate assay demonstrated that the RP extract had higher antioxidant capacity $(p<0.001)$ compared to AP. Further, antioxidant capacity and anti-proliferative activity were lower $(p<0.001)$ in AP and RP in the absence of polyphenols compared to the crude extract.

Conclusion: Root contains higher levels of flavonoids than the aerial part. Moreover, the presence of polyphenols is required for antioxidant and anti-proliferative activities of both AP and RP.

Keywords: Phyllanthus debilis, Polyphenols, Antioxidant activity, Anti-proliferative activity, RD, CC1

Abbreviations: AAE, Ascorbic acid equivalent; AP, Aerial parts; CC1, normal rat liver cells; DPPH, 1,1-Diphenyl-2picrylhydrazyl; EGCG, (-) -Epigallocatechingallate; GAE, Gallic acid equivalent; MTT, 3 4, 5-(dimethylthiazol-2-yl) 2-5diphenyl tetrazolium bromide; PFAP, Polyphenol free aerial parts; PFRP, Polyphenol free root parts; PVPP, Polyvinyl polypyrrolidone; RD, Rhabdomyosarcoma cells; RP, Root parts; TPC, Total polyphenolic content

\section{Background}

Reactive free radicals are constantly generated in human body through biological reactions. Reactive oxygen species (ROS) such as hydroxyl radical $(\mathrm{OH})$, hydrogen peroxide $\left(\mathrm{H}_{2} \mathrm{O}_{2}\right)$, superoxide radical $\left(\mathrm{O}_{2}\right)$ and singlet oxygen $\left(\mathrm{O}_{2}\right)$ and reactive nitrogen species (RNS) such as nitric oxide $(\mathrm{NO} \cdot)$, peroxynitrite $\left(\mathrm{ONOO}^{-}\right)$and nitrogen

\footnotetext{
* Correspondence: indunilsree@gmail.com

'Department of Biochemistry and Molecular Biology, University of Colombo, Faculty of Medicine, Colombo 08, Sri Lanka

Full list of author information is available at the end of the article
}

dioxide $\left(\mathrm{NO}_{2}\right)$ are the main sources of reactive free radicles. The production of free radicals are neutralized by endogenous antioxidants and enzymes, however excessive production of reactive molecules causes oxidative stress. As a result they oxidize biologically important macro molecules such as DNA, proteins, lipids and carbohydrates [1]. DNA strand breaks and abnormal DNA linkages caused by ROS and RNS are closely associated with carcinogenesis [2]. The consequence of oxidative stress is also associated with cardiovascular, metabolic, inflammatory diseases and various neurodegenerative 
diseases including Alzheimer's disease, Parkinson's disease and multiple sclerosis [3].

Plants produce broad spectrum of polyphenolic compounds as secondary metabolites for their survival under stress conditions. Polyphenols have an ability to neutralize free radicals by donating them electrons or hydrogen atoms which may play a vital role in health benefits [4].

Phyllanthus debilis (Elapitawakka/Bim nelli) is an annual plant found in Sri Lanka. The genus Phyllanthus (Euphorbiaceae) contains about 800 species in worldwide and most of these plants have been used as drugs in traditional systems of medicine all over the world [5]. Studies carried out on P.debilis with authenticated plant are very limited up-to date. Aqueous extract of P.debilis has shown anti-hyperglycemic and hypoglycemic activity in mice [6]. Further analgesic and anti-inflammatory activity have been demonstrated for the petroleum ether extract of the whole plant in animal models [7]. Anticancer, antibacterial and antioxidant activity have also reported with different solvent extracts in vitro [5, 8-10].

The whole plant of P.debilis or its parts are used to prepare porridge or 'decoction' in traditional medicine and folk medicine to treat ailments such as liver complications, diabetes mellitus and skin diseases in Sri Lanka [11]. The present study was carried out to explore the antioxidant activity and the potential anti-proliferative activity of the water extract of P.debilis plant as used in traditional systems of medicine. Since it is important to understand the contribution of polyphenols on antioxidant and anti-proliferative activity, further investigations were carried out with the plant extracts after removing their polyphenols.

\section{Methods}

\section{Chemicals and equipment}

Gallic acid, 2-deoxy-D-ribose, Folin-Ciocalteu's reagent and other chemicals needed for cell culture and cell viability studies were purchased from Sigma Chemicals Co. (P.O. Box 14508, St. Louis, MO 63178 USA). 1,1-Diphenyl-2picrylhydrazyl (DPPH) free radical, epigallocatechin gallate (EGCG), aluminium chloride, polyvinyl-polypyrrolidone (PVPP) were purchased from Fluka (Flukachemie $\mathrm{GmbH}$, CH-9471 Buchs). L-Ascorbic acid, hydrogen peroxide, $\mathrm{N}$-(1-naphthyl)-ethylene diaminedihydro chloride and ethanol were purchased from $\mathrm{BDH}$ Chemicals $(\mathrm{BDH}$ Chemicals Ltd, Poole, England). All chemicals used were of analytical grade.

SHIMADZU UV 1601 UV/Visible spectrophotometer (Shimadzu Corporation, Kyoto, Japan) was used to read the absorbance. LFT 600 EC freeze dryer was used to freeze-dry the plant extracts (LFT $600 \mathrm{EC},-90-95{ }^{\circ} \mathrm{C}$ temperature, 10 valves with Hitachi pump). Cells used for the assessment of anti-proliferative activity (RD, CC1) were incubated at $37{ }^{\circ} \mathrm{C}$ in a humidified $\mathrm{CO}_{2}$ incubator
(SHEL LAB/Sheldon manufacturing Inc., Cornelius, OR 97113, USA). Olympus (1X70-S1F2) inverted fluorescence microscope (Olympus Optical Co. Ltd. Japan) and digital camera (MDC 200 (USB 2.0) 2 M pixels with CCD chip) were used for assessment and imaging of cell morphology.

RD cell line was kindly donated by Dr Sunethra Gunasena, Medical Research Institute, Colombo 08, Sri Lanka and CC1 (Normal rat liver fibroblast) cell line was obtained from Dr. Panjwani Center for Molecular Medicine and Drug Research, University of Karachi, Pakistan.

\section{Plant materials}

Phyllanthus debilis plants in the seeding stage were collected from Pannipitiya area in the Colombo district, Sri Lanka (June 2014). The plant was taxonomically identified and voucher specimens were deposited in Botany Department, Bandaranayaka Memorial Aurveda Research Institute, Nawinna, Colombo, Sri Lanka (Deposition number: $755 / \mathrm{a})$.

\section{Preparation of the decoctions}

The plant materials were washed in distilled water followed by deionized water and air dried. The aerial parts and the root parts were separated and freeze dried until a constant weight was obtained. Dried samples were ground using a kitchen blender. The powdered aerial parts $(50 \mathrm{~g})$ were refluxed with $500 \mathrm{~mL}$ of deionized water for $3 \mathrm{~h}$ in triplicate. The roots were pooled together and the powdered roots $(50 \mathrm{~g})$ were refluxed as previously. Decoctions were filtered through a glass funnel plugged with cotton wool, then through a Whatman filter paper. Filtrate was centrifuged at 10,000 rpm for $15 \mathrm{~min}$ and the supernatant was freeze dried. The freeze dried samples were weighed and stored at $-20{ }^{\circ} \mathrm{C}$ in sterile glass bottles until further use. The yield was calculated as a percentage of the dried plant material.

\section{Removal of polyphenols}

Polyphenols were removed using Polyvinyl polypyrrolidone (PVVP) column as described by Soysa (1997) $[12,13]$. Briefly, a cotton wool plug was placed inside a $5 \mathrm{~cm}^{3}$ syringe after removing the plunger and the needle. Syringe was filled with PVPP $(1.7 \mathrm{~g})$. Water extract of AP and RP (3 mL) was layered over the PVPP column. The PVPP column was placed in a $15 \mathrm{~mL}$ falcon tube and centrifuged at 2,000 g for $10 \mathrm{~min}$. Centrifugation was repeated for 6 times with the same column adding $1 \mathrm{~mL}$ of the extract and each fraction was collected to separate tubes. The first fraction was discarded and remaining fractions were analyzed for the presence polyphenols. The Absorbance of AP (aerial parts) and RP (root parts) before and after PVPP treatment were 
scanned for wavelengths using a UV/Visible scanning spectrophotometer.

\section{Determination of total polyphenolic and flavonoid content}

Total polyphenolic content (TPC) of the AP and RP were determined using Foiln-Ciocalteu's method [14]. Gallic acid was used to construct the standard curve and total phenolic content was expressed as w/w\% gallic acid equivalents (GAE w/w \%).

The flavonoid content of the extracts was determined by aluminum chloride colorimetric assay [15]. Calibration curve was plotted using EGCG (- (-) -Epigallocatechingallate) standard and flavonoid content was expressed as w/w\% EGCG equivalents (EGCGE w/w \%).

\section{Determination of total proanthocyanidins}

A volume of $2 \mathrm{ml}$ of vanillin reagent $(1 \mathrm{~g}$ vanillin in $50 \mathrm{~mL}, 70 \% \mathrm{H}_{2} \mathrm{SO}_{4}$ ) was mixed with $200 \mu \mathrm{L}$ of the sample $(400,500,700 \mu \mathrm{g} / \mathrm{mL})$. The resulting mixture was allowed to stand for $15 \mathrm{~min}$ at room temperature. The absorbance was determined at $500 \mathrm{~nm}$ [16]. Calibration curve was constructed using EGCG and the total proanthocyanidin content was expressed as w/w \% EGCG equivalent.

\section{Qualitative analysis of plant phytochemicals}

Qualitative analysis for the phytochemicals were carried out using the methods described by Saeed et al., (2012) for alkaloids, tannins, terpenes, saponins, cardiac glycosides present in the water extracts of the plant [17].

\section{Phosphomolybdate assay for total antioxidant capacity}

Total antioxidant capacity was determined using phosphomolybdate method [18]. Results were expressed as $\mathrm{w} / \mathrm{w} \%$ ascorbic acid equivalent (AAE).

\section{2,2'- Diphenyl-1-picrylhydrazyl (DPPH) radical scavenging activity assay}

In vitro antioxidant activity of the AP, RP, PFAP and PFRP were determined using stable free radical 2,2'diphenyl-1-picrylhydrazyl (DPPH) [15]. Results were expressed as percentage inhibition calculated from the formula (1).

$$
\begin{aligned}
& \% \text { Scavenge of DPPH free radical } \\
& =\frac{(A b \text { of control }- \text { Ab of sample }) X 100}{A b \text { of control }}
\end{aligned}
$$

\section{Hydroxyl radical scavenging assay}

Hydroxyl radical scavenging activity of AP and RP was determined in lyophilized plant extracts. Fenton reaction was used to generate hydroxyl radicals in vitro
Table 1 Extraction yield, polyphenolic, flavonoid and proanthocyanidincontent of extracts

\begin{tabular}{lccl}
\hline $\begin{array}{l}\text { Part of the } \\
\text { plant }\end{array}$ & $\begin{array}{l}\text { Total polyphenolic } \\
\text { content (w/w\% GAE) }\end{array}$ & $\begin{array}{l}\text { Flavonoid } \\
(\mathrm{w} / \mathrm{w} \% \text { EGCGE) }\end{array}$ & $\begin{array}{l}\text { Proanthocyanidin } \\
(\mathrm{w} / \mathrm{w} \% \mathrm{EGCGE})\end{array}$ \\
\hline $\begin{array}{l}\text { Aerial parts } \\
(n=3)\end{array}$ & $12.0 \pm 0.6$ & $65.9 \pm 3.6^{*}$ & $13.8 \pm 2.2$ \\
Roots $(n=3)$ & $17.8 \pm 3.7$ & $82.6 \pm 4.6^{*}$ & $14.5 \pm 3.0$ \\
\hline
\end{tabular}

Results are expressed as mean \pm SD. GAE -Gallic acid equivalent; EGCGE- (-) Epigallocatechingallate equivalent). ${ }^{*} P<0.001$ when compared AP with RP. AP: aerial parts, RP: roots

[19]. The assay is based on quantification of degradation product of 2-deoxyribose by condensation with TBA. The percentage scavenging activity of hydroxyl radical was calculated using the formula (1). Ascorbic acid served as the positive control.

\section{Hydrogen peroxide scavenging activity}

Assay was carried out according to the method developed by Fernando and Soysa [20]. Percentage scavenging activity was calculated using the formula (1). Ascorbic acid served as the positive control.

\section{Ferric ion reducing power}

The reducing ability to convert ferric ions to ferrous ions by AP and RP was carried out as previously described [15]. Ascorbic acid served as the positive control.

\section{Nitric oxide radical scavenging}

This assay is based on Griess Illosvoy reaction [15]. The pink azo-dye generated during reaction was measured at $540 \mathrm{~nm}$. Ascorbic acid served as the positive control.

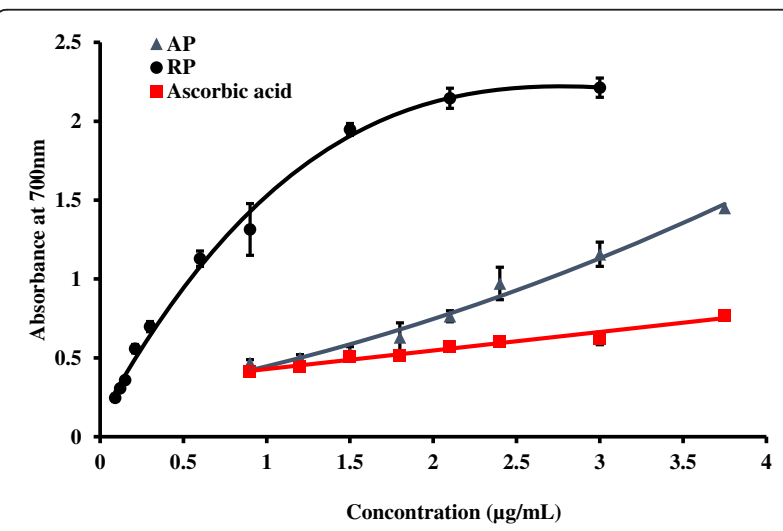

Fig. 1 Ferric ion reducing capacity of plant extracts and L-Ascorbic acid standard at different concentrations. The results are presented as mean \pm SD for shoot samples $(n=3)$, root samples $(n=3)$ and LAscorbic acid $(n=3)$ 
Table $2 \mathrm{EC}_{50}$ values for free radical scavenging assays for hydroxyl, nitric oxide assay and hydrogen peroxide with relevant positive standards

\begin{tabular}{lllll}
\hline EC 50 values & $\begin{array}{l}\mathrm{OH} \\
(\mu \mathrm{g} / \mathrm{mL})\end{array}$ & $\begin{array}{l}\mathrm{NO} \\
(\mu \mathrm{g} / \mathrm{mL})\end{array}$ & $\begin{array}{l}\mathrm{H}_{2} \mathrm{O}_{2} \\
(\mu \mathrm{g} / \mathrm{mL})\end{array}$ & $\begin{array}{l}\text { Total antioxidant } \\
\text { capacity (w/w \% AAE) }\end{array}$ \\
\hline $\begin{array}{l}\text { AP(Aerial } \\
\text { parts) }(n=3)\end{array}$ & $49.27 \pm 4.75^{*}$ & $211.05 \pm 7.61^{*}$ & $42.54 \pm 2.23^{*}$ & $37.7 \pm 3.2$ \\
$\begin{array}{l}\mathrm{RP}(\text { Root }) \\
(n=3)\end{array}$ & $27.77 \pm 3.26^{*}$ & $170.75 \pm 3.16^{*}$ & $30.23 \pm 3.35^{*}$ & $35.3 \pm 5.6$ \\
$\begin{array}{l}\text { Gallic acid } \\
(n=3)\end{array}$ & $27.37 \pm 1.89$ & $\mathrm{~N} / \mathrm{A}$ & $\mathrm{N} / \mathrm{A}$ & $\mathrm{N} / \mathrm{A}$ \\
$\begin{array}{l}\text { Ascorbic acid } \\
(n=3)\end{array}$ & $\mathrm{N} / \mathrm{A}$ & $212.58 \pm 2.87$ & $13.82 \pm 1.11$ & $\mathrm{~N} / \mathrm{A}$
\end{tabular}

Significant difference at ${ }^{*} P<0.001$ when compared RP with AP. AAE: Ascorbic acid equivalent, N/A: Not applicable

\section{Antiproliferative activity}

\section{Cell culture}

RD (Rhabdomyosarcoma) and CC1 (normal rat liver) cells were cultured in tissue culture flasks with DMEM (Dulbecco's Modified Eagle's Medium) supplemented with $10 \%$ FBS, $3 \%$ glutamine, 1\%penicillinstreptomycin, and 1 M HEPES (4-(2-Hydroxyethyl) piperazine-1-ethanesulfonic acid) buffer in humidified $\mathrm{CO}_{2}$ incubator in $37^{\circ} \mathrm{C}$.

\section{Cell morphology}

Cell morphology was observed before and after the treatment of the extract at different concentrations using an inverted fluorescence microscope. Images of the cells were captured.

MTT ((3-(4,5-Dimethylthiazol-2-yl)-2,5diphenyltetrazoliumbromide)) assay

Cells were plated in 24-well flat bottom tissue culture plates at a density of $2 \times 10^{5}$ cells/well and kept overnight at $37{ }^{\circ} \mathrm{C}$ in a $\mathrm{CO}_{2}$ incubator to obtain a $70 \%$ confluent mono layer. The cells were treated with AP, RP, PFAP and PFRP at different concentrations for

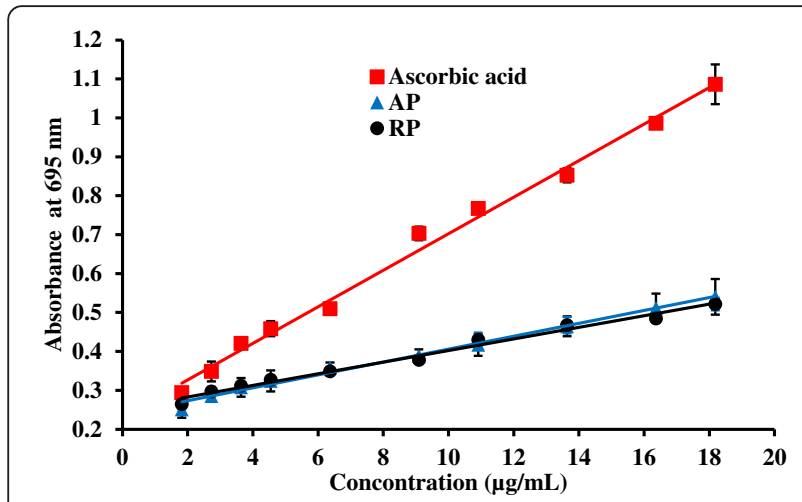

Fig. 2 Total antioxidant capacity of plant extracts and L-Ascorbic acid at different concentrations. The results are presented as mean \pm SD for AP (Aerial parts) $(n=3)$, root samples (RP) $(n=3)$ and L-Ascorbic acid $(n=3)$

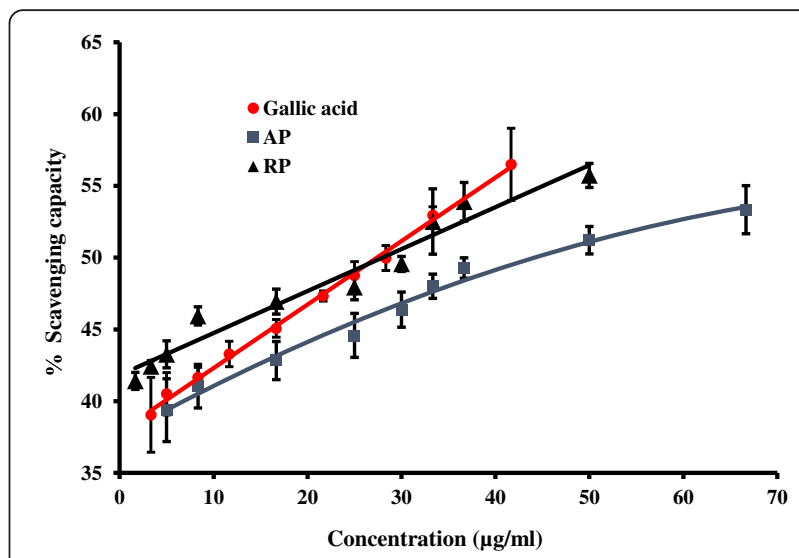

Fig. 3 Dose response curve for percentage hydroxyl radical scavenging of plant extracts and L-Ascorbic acid standard. The results are presented as mean \pm SD for aerial parts (AP), root parts (RP) and gallic acid standard

$24 \mathrm{~h}$. Cells for negative controls were exposed to the same conditions without the plant extract. Cycloheximide $(0.1 \%, 50 \mu \mathrm{l})$ served as the positive control. Medium was replaced by MEM (1 ml) and MTT reagent $(100 \mu \mathrm{l}, 5 \mathrm{mg} / \mathrm{ml})$. The contents were incubated for $4 \mathrm{~h}$ at $37{ }^{\circ} \mathrm{C}$. Isopropyl alcohol $(750 \mu \mathrm{l})$ in $0.05 \mathrm{M}$ $\mathrm{HCl}$ was added to dissolve MTT crystals. Absorbance was recorded at $570 \mathrm{~nm}$. Percentage cell viability was calculated using the formula 2 [21].

$$
\% \text { Cytotoxicity }=\frac{(\text { Ab of Negative control }- \text { Ab of sample }) X 100}{A b \text { of Negative control }}
$$

\section{Statistics and calculations}

Each experiment was performed at least in triplicate for three lyophilized samples prepared from aerial extracts and for the pooled sample (lyophilized) of the root extract. Calibration curves were considered as linear if

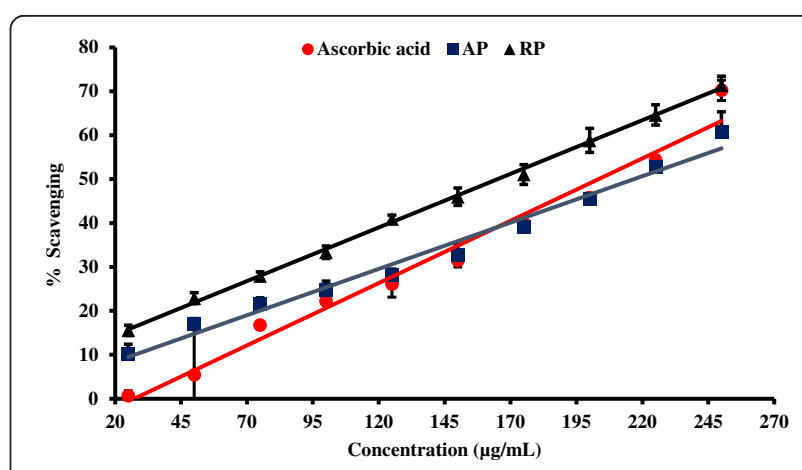

Fig. 4 Dose response curve of nitric oxide radical scavenging percentage of plant extracts and L-Ascorbic acid standard. The results are presented as mean \pm SD for AP $(n=3)$, root samples (PR) $(n=3)$ and Gallic acid standard $(n=3)$ AP: Aerial parts, RP: Root parts 


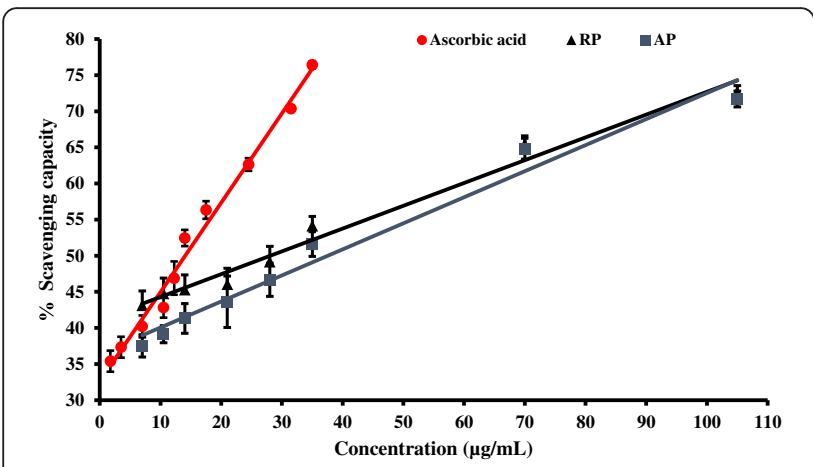

Fig. 5 Dose response curve of percentage hydrogen peroxide scavenging ability of plant extracts and L-Ascorbic acid standard. The results are presented as mean \pm SD for shoot samples $(n=3)$, root samples $(n=3)$ and L-Ascorbic acid standard $(n=3)$

$\mathrm{R}^{2}>0.99$. The $\mathrm{EC}_{50}$ values were calculated from either linear or logarithmic dose response curves where $R^{2}>$ 0.95 was considered as linear. Student $t$ test was carried out for the statistical calculations using Microsoft Excel.

\section{Results and discussion}

\section{Extraction yield, total phenolic, flavonoid and}

\section{proanthocyanidin content}

The extraction efficiency of aerial parts and the pooled sample of the roots were $12.1( \pm 0.5)$ and $12.5 \%$ of the dry weight respectively. Total polyphenol content, flavonoid and proanthocyanidin content of extracts are depicted in Table 1. Mean values for TPC, flavonoid and proanthocyanidin content are higher in roots. However a significant difference was observed only with flavonoid content which is a subgroup of polyphenols. Significant difference was not observed for both polyphenolic and proanthocyanidin content between AP and RP (Table 1).

Plant polyphenols are secondary metabolites, which synthesize for their defense against abiotic and biotic stress conditions. They also play numerous roles in biological systems such as antioxidants, antimicrobial and anticancer agents [22]. Gallic acid, rutin, corilagin, furosin and geraniin are some of the polyphenols characterized in aerial parts of P.debilis [10]. Flavonoids are also a subset of polyphenols. They involve in regulatory mechanisms in cell proliferation and differentiation to protect eukaryotic cells from oxidative stress through regulating the activity of different protein kinases [23]. Flavonoids have ability to scavenge free radicals and also serve to chelate metals that generate free hydroxyl radicals via the Fenton reaction [24]. The highest amount of flavonoid content was observed in RP than AP $(P<0.001)$ (Table 1). Proanthocyanidins is a subset of flavonoid which is synthesized in flavonoid biosynthetic pathway. They are oligomers of flavan-3-ol units with diverse biological activities [25]. Both roots and aerial part showed similar proanthocyanidin content. The present study also showed the presence of alkaloids, tannins, terpenes and saponins but the absence of cardiac glycosides. However a previous study reported that absence of saponin, triterpenoids, and tannins in p.deblis [26].

\section{Ferric ion reducing power}

Reducing potential is a marker of antioxidant capacity and it was assessed by ferric ion reducing assay. Ferric ions can be reduced to ferrous ions by the antioxidants present in the plant extracts. Ferric ion formation is monitored through the blue green colored complex at $700 \mathrm{~nm}$ [27]. Both parts of the plant showed higher reducing ability than the ascorbic acid standard. The capacity to reduce $\mathrm{Fe}^{3+}$ by the root extracts is significantly higher $(p<0.05)$ than the ascorbic acid or AP at all the concentrations studied. Furthermore the root showed a reducing capacity even at $0.2 \mu \mathrm{g} / \mathrm{mL}$ (Fig. 1).

\section{Total antioxidant capacity}

The assay is based on the reduction of molybdenum (VI) to molybdenum (V) which forms a green chromophore with phosphate in the acidic medium [28]. Total antioxidant capacity of both AP and RP depicts no
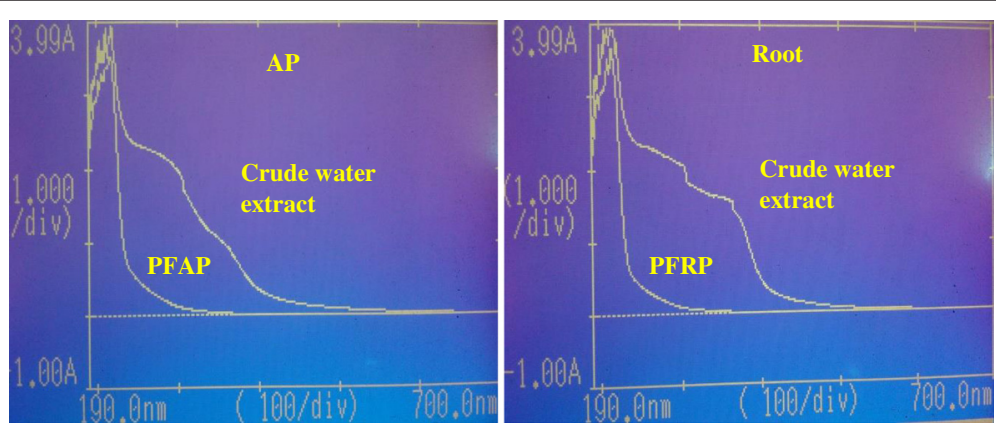

Fig. 6 The photometric scanning spectrum obtained for the root and shoot samples before and after the treatment with PVPP. AP: Aerial parts, PFAP: polyphenol free aerial parts, PFRP: Polyphenol free root parts 
Table 3 DPPH scavenging assay, $\mathrm{EC}_{50}$ values with the presence and absence of polyphenols

\begin{tabular}{lll}
\hline Plant extract & $\begin{array}{l}E C_{50} \text { values before removal } \\
\text { of polyphenols }(\mu \mathrm{g} / \mathrm{mL})\end{array}$ & $\begin{array}{l}E C_{50} \text { values of after removal } \\
\text { of polyphenols }(\mu \mathrm{g} / \mathrm{mL})\end{array}$ \\
\hline $\begin{array}{l}\text { AP(Aerial parts) } \\
(n=3)\end{array}$ & $8.6 \pm 0.4$ & $695.1 \pm 4.6$ \\
$\begin{array}{l}\text { RP (Roots) } \\
(n=3)\end{array}$ & $3.7 \pm 0.1$ & $583.3 \pm 12.3$ \\
$\begin{array}{l}\text { Ascorbic acid } \\
(n=3)\end{array}$ & $3.3 \pm 0.3$ & - \\
\hline
\end{tabular}

significance difference (Table 2 and Fig. 2). Ferric ion reducing power results indicate higher reducing potential of root but molybdenum reduction assay demonstrates no significant difference in antioxidant potential in both extracts. This showed that though the capacity to reduce $\mathrm{Fe}^{3+}$ to $\mathrm{Fe}^{2+}$ is higher in roots, overlapping curves signifies (Fig. 2) that the capacity to reduce $\mathrm{Mo}^{6+}$ to $\mathrm{Mo}^{5+}$ is similar in both parts. The positive control, ascorbic acid also showed different behavior in reducing power between ferric ion and molybdenum (VI) ion.

\section{Hydroxyl radical scavenging assay}

Hydroxyl radicals are generated by reducing the oxygen molecule to water and it is one of the main sources of reactive oxygen species in biological systems [29]. The values obtained for $\mathrm{EC}_{50}$ show that hydroxyl radical scavenging ability of RP is significantly higher than AP and no significant difference were found between root and ascorbic acid (Table 2). Further it was observed that the percentage scavenging ability of RP is higher at lower concentrations (below around $20 \mu \mathrm{g} / \mathrm{mL}$ ) than the gallic acid. Scavenging capacity of AP is parallel to that of the gallic acid standard (Fig. 3).

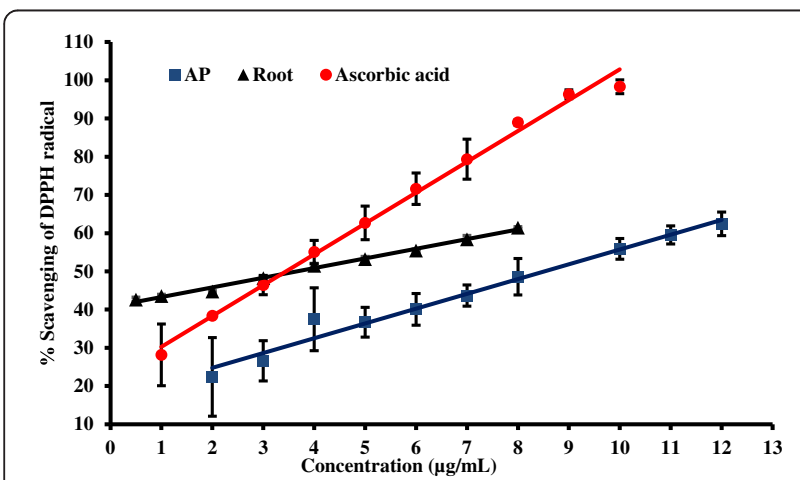

Fig. 7 The dose dependent response curves for percentage scavenging of DPPH by water extracts of root and aerial parts (AP) of P.debilis plant comparison with $L$-Ascorbic acid. The results are presented as mean \pm SD for shoot $(n=3)$, root $(n=3)$ and L-Ascorbic acid $(n=3)$

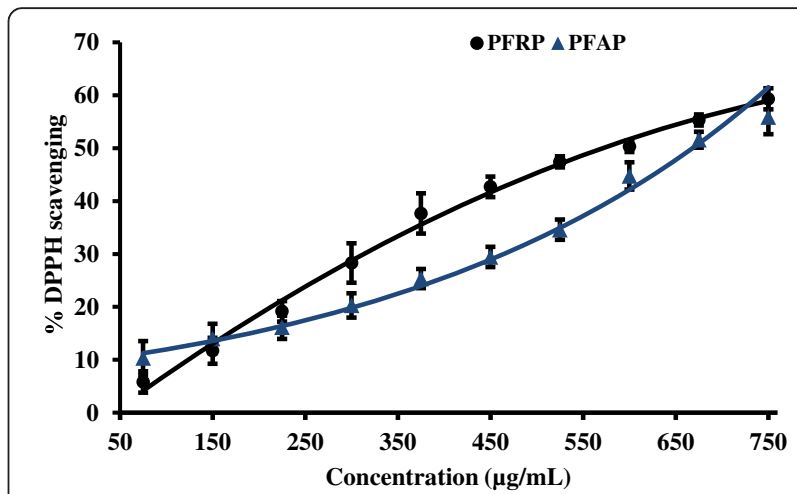

Fig. 8 The dose dependent percentage scavenging potential of DPPH in the absence of polyphenols in AP and RP $(n=3)$. PFAP: Polyphenol free aerial parts, PFRP: Polyphenol free root parts. The results are presented as mean \pm SD for $\mathrm{AP}$

\section{Nitric oxide radical scavenging assay}

Figure 4 Nitric oxide (NO) is a free radical and a signaling molecule which is responsible for various biological functions. It has been found that the peroxynitrite derived from NO under oxidative conditions is a highly reactive radical which can damage macromolecules [30]. The Present study showed that roots of P.debilis has high NO scavenging capacity and the $\mathrm{EC}_{50}$ is lower than the ascorbic acid $(p<0.001)$ (Table 2$)$. These observations suggest that the possibility of using P.debilis in the treatment of degenerative diseases by scavenging nitric oxide free radicals. However further research should be carried out in this regard.

\section{Hydrogen peroxide scavenging assay (Fig. 5)}

Hydrogen peroxide is a metabolic byproduct results from the action of superoxide dismutase with superoxide radical. Superoxide radicals have a capability of generating reactive oxygen species [31]. Hydrogen peroxide is less toxic than superoxide radical in biological systems. Both roots and aerial parts of the plants showed moderate activity against $\mathrm{H}_{2} \mathrm{O}_{2}$ scavenging activity. However the EC 50 values were higher than the ascorbic acid reference standard (Table 2).

\section{Spectrum analysis}

The presence of polyphenols in both shoot and roots is evidenced by showing an absorbance peak between 190 and $700 \mathrm{~nm}$. The broad peak observed around $235 \mathrm{~nm}$ was remained constant while the signals between the 230 to $500 \mathrm{~nm}$ were disappeared from both parts of the plant after PVPP treatment (Fig. 6). Data published by Shela et al., (1993) states that polyphenolic compounds in white wine had a maximum absorbance between 250 - $350 \mathrm{~nm}$ [32]. Similar observations were also found in the present study. 


\section{Cell morphology}
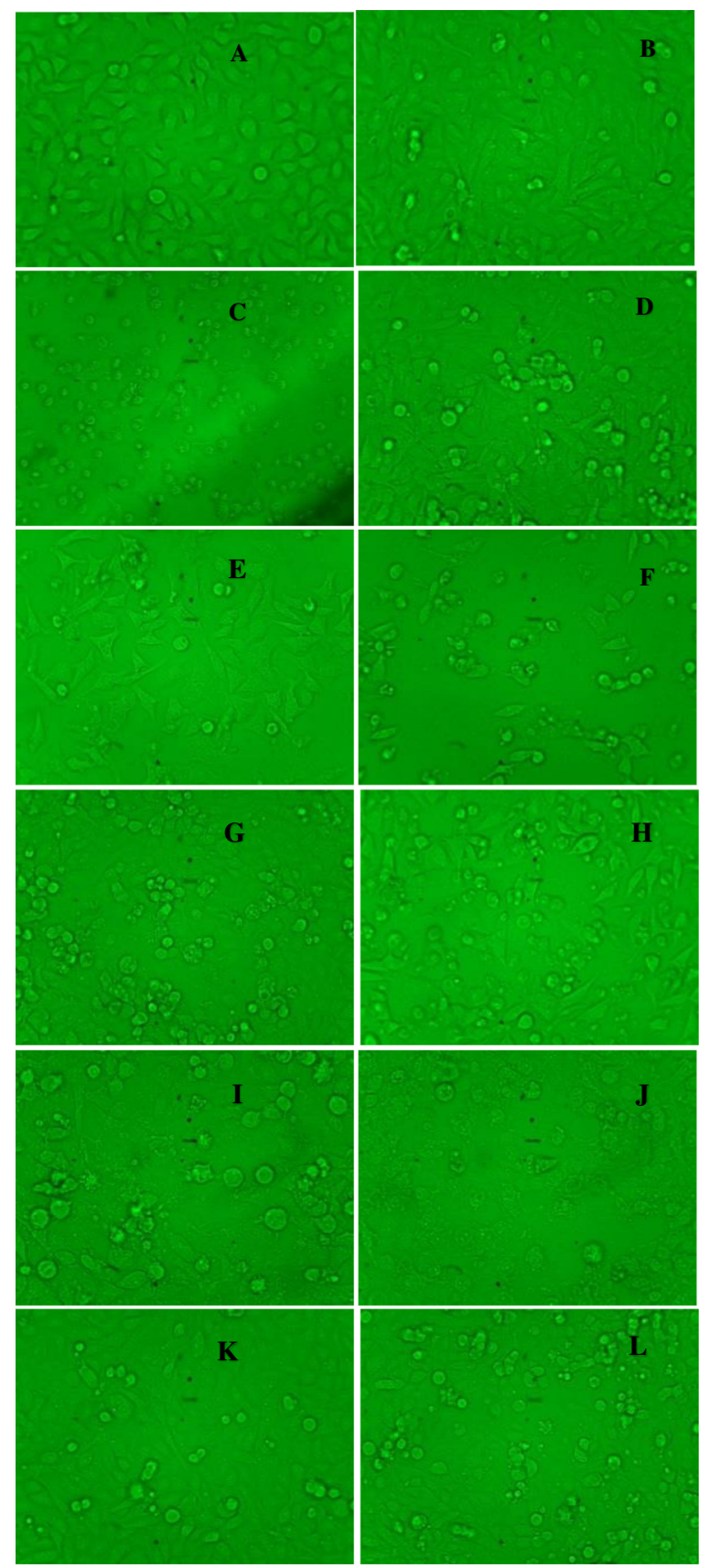

Fig. 9 Morphological changes of cells observed after $24 \mathrm{~h}$ exposure of AP and RP extracts and cycloheximide (positive control) under light microscopy. $\mathbf{a}$ and $\mathbf{b}$ are negative controls of RD and CC1 cells. c and $\mathbf{d}$ are positive controls of RD and CC1 cells treated with cycloheximide $(0.1 \%, 50 \mu \mathrm{l})$ as the positive control respectively. e \& f: RD Cells treated with AP at concentrations 200 and $500 \mu \mathrm{g} / \mathrm{mL}$, respectively. $\mathbf{g} \& \mathbf{h}$ : CC1 Cells treated with AP at concentrations 800 and $1000 \mu \mathrm{g} / \mathrm{mL}$, respectively. $\mathbf{i} \& \mathbf{j}$ RD cells treated with RP at concentrations at 200 and $500 \mu \mathrm{g} / \mathrm{mL}$. $\mathbf{k} \& \mathbf{I}$ : CC1 cells treated with $\mathrm{RP}$ at concentrations 800 and $1000 \mu \mathrm{g} / \mathrm{mL}$, respectively (20X)
Table 4 Comparison of $\mathrm{EC}_{50}$ values of the MTT cytotoxicity assay

\begin{tabular}{lll}
\hline & AP $(n=3)$ & RP $(n=3)$ \\
\hline RD cell line $(\mu \mathrm{g} / \mathrm{mL})$ & $287.16 \pm 8.39^{*}$ & $216.52 \pm 11.90^{*}$ \\
CC1 cell line $(\mu \mathrm{g} / \mathrm{mL})$ & $555.03 \pm 4.21^{*}$ & $842.01 \pm 7.53^{*}$ \\
\hline${ }^{*} P<0.01$ when compared between AP (Aerial parts) and RP (Root parts)
\end{tabular}

Scavenging capacity for DPPH radical in the presence and absence of polyphenolic compounds of the plant extracts Antioxidants readily react with DPPH radical change its original purple color into yellow [15]. The DPPH radical scavenging capacity of the root is comparable to ascorbic acid and significantly higher $(P<0.001)$ than the aerial parts (Table 3 ). Interestingly, DPPH scavenging capacity of the root extract at lower concentrations is higher than that of ascorbic acid but lower at high concentrations (Fig. 7). A previous study has reported that methanolic extracts of P.debilis has high DPPH scavenging activity and the results are comparable with the present study [33].

Polyvinyl polypyrolidone (PVPP) is highly cross linked polymer which has high affinity towards polyphenols [13, 34]. In the absence of polyphenols both root and aerial parts showed high $\mathrm{EC}_{50}$ values for the $\mathrm{DPPH}$ assay. The $\mathrm{EC}_{50}$ ratios with the absence and presence of polyphenols are over 100 fold for both extracts. These results indicate that polyphenols are the main contributory factor for DPPH radical scavenging activity and involvement of non-polyphenols for the antioxidant activity is negligible. Spectrophotometric analysis suggests that the substance(s) which have maximum absorbance around $235 \mathrm{~nm}$ are not responsible for scavenging of DPPH (Fig. 8 and Table 3).

\section{Cell morphology \\ Anti-proliferative activity of $A P$ and $R P$ against $R D$ and $C C 1$ cells}

Figure 9 depicts the morphological changes of RD cells treated with AP and RP extracts. Shrunken cells with condensed cytoplasm and membrane blebbing characteristics to apoptosis were observed in RD cells treated with plant extracts [35]. The cell death was concentration dependent for both AP and RP with the cell lines investigated. Normal rat liver fibroblast cells(CC1), showed apoptotic features characteristic to apoptosis only at high concentrations.

Anti-proliferative activity was high in RD cells by both AP and RP extracts compared to the CC1 cells (Table 4 \& Fig. 10). Even at a concentration such as $1200 \mu \mathrm{g} / \mathrm{mL}$, the percentage cytotoxicity of CC1 cells was only 58.99 $\pm 2.43 \%$ and $54.11 \pm 0.88 \%$ for AP and RP extracts respectively. Several compounds which have been isolated from P.deblis provide evidence for antioxidant and anti- 

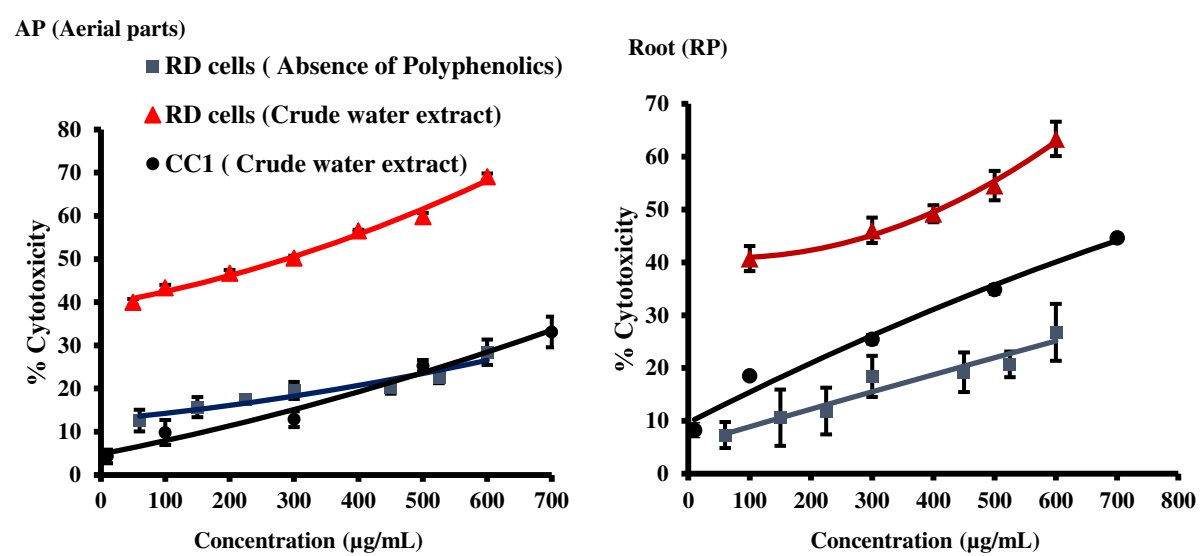

Fig. 10 Dose dependent cytotoxic effect of AP and RP with RD and CC1 cells and cytotoxicity of polyphenol absence samples with RD cells, after $24 \mathrm{~h}$ exposure

proliferative activity confirmed in the present study. Gallic acid, rutin, corilagin, furosin and geraniin isolated from $P$. deblis and geraniin have shown high DPPH scavenging activity $[10,36]$. It is reported that geraniin has antioxidant properties and induces apoptotic cell death in human lung adenocarcinoma cells in vitro and in vivo [37]. Gallic acid is a common naturally occurring phenol found inplants used for therapeutic purposes including phyllanthus species [38]. It acts as an antioxidant and exerts anti-proliferative effect on glioma T98G cells via dose-dependent epigenetic regulation mediated by miRNAs $[39,40]$. The authors have further reported that the anticancer activity is based on its antioxidant effects.

The $\mathrm{EC}_{50}$ for MTT assay is significantly high $(P<0.001)$ for the $\mathrm{RD}$ cells treated with polyphenol free extracts compared to the crude extract (Figs. 9 \& 10 and Table 4). Dose dependent increase in cytotoxicity was observed even in the absence of polyphenols at high concentrations. However the percentage cell viability in the absence of polyphenols was only $28.41 \pm 2.94$ and $26.77 \pm 5.37 \%$, even at concentration of $600 \mu \mathrm{g} / \mathrm{mL}$ with AP and RP respectively. At the same concentration AP and RP had $69.09 \pm 0.70$ and $63.36 \pm 1.60 \%$ cell viably respectively.

Hypophyllanthin and Phyllanthin are non polyphenolic compounds found in some phyllanthus species including $P$. deblis have shown that they exhibit anti-proliferative and antioxidant activity in vitro and vivo [38, 41]. The presence of non-phenolics which have anti-proliferative activity may have contributed to the cell death in the PVPP treated extracts (Fig. 10). However the contribution is low compared to the phenolic compounds.

The evidence supports that polyphenolic compounds are essentially responsible for cell death activating via the increase production of ROS (Reactive oxygen species). Based on the results it may be more effective to prescribe root instead of whole plant in therapy.

\section{Conclusions}

The present study reveals that antioxidant activity and anti-proliferative activity are higher in root compared to aerial parts which associate with their phenolic content. Polyphenolic compounds present in both $\mathrm{RP}$ and AP extracts show a significant contribution for antioxidant activity and anti-proliferative activity against $\mathrm{RD}$ cell line. It was also found that $P$. debilis does not show cytotoxic activity against CC1 control cells as same as the cancer cells.

\section{Acknowledgements}

We acknowledge University of Colombo, Sri Lanka for the financial assistance by awarding the Research Grant AP/3/2/2014/RG/11. The authors are grateful to Dr. S. Gunasena Medical Research Institute, Colombo 08, Sri Lanka for providing the RD cell line, Ms. Sudeepa Sugathadasa and Ms. Pushpa Jeewandara,

Department of Botany, Bandaranayake Memorial Ayurvedic Research Institute, Nawinna, Colombo, Sri Lanka for the identification of the plant.

The technical assistance offered by technical staff, Department of Biochemistry \& Molecular Biology, Faculty of Medicine, University of Colombo, is also acknowledged.

Availability of data and material

The datasets generated during and/or analyzed during the current study are available from the corresponding author on reasonable request.

\section{Authors' contributions}

Designing the project, data interpretation and revising the manuscript was carried out by PS. SW supervised the project. All the experimental work, data analysis and drafting of the manuscript were carried out by DP. All authors read and approved the final manuscript.

Competing interests

The authors declare that they have no competing interests.

Consent for publication

Not applicable.

Ethics approval and consent to participate Not applicable. 


\section{Author details}

Department of Biochemistry and Molecular Biology, University of Colombo, Faculty of Medicine, Colombo 08, Sri Lanka. ${ }^{2}$ Department of Obstetrics \& Gynaecology, University of Colombo, Faculty of Medicine, Colombo 08, Sri Lanka.

\section{Received: 2 July 2016 Accepted: 25 August 2016}

Published online: 01 September 2016

\section{References}

1. Lobo V, Patil A, Phatak A, Chandra N. Free radicals, antioxidants and functional foods: Impact on human health. Pharmacogn Rev. 2010;4(8):118-26.

2. Bennett LI, Rojas $\mathrm{S}$, Seefeldt T. Role of antioxidants in the prevention of cancer. J Exp Clin Med. 2012;4(4):215-22.

3. Ramalingam M, Kim SJ. Reactive oxygen/nitrogen species and their functional correlations in neurodegenerative diseases. J Neural Transm (Vienna). 2012;119(8):891-910.

4. Tsao R. Chemistry and biochemistry of dietary polyphenols. Nutrients. 2010; 2(12):1231-46.

5. Komuraiah A, Bolla K, Rao KN, Ragan A, Raju VS, Charya MAS. Antibacterial studies and phytochemical constituents of South Indian Phyllanthus species. Afr J Biotechnol. 2009;8(19):4991-5.

6. Wanniarachchi KK, Peiris LDC, Ratnasooriya WD. Antihyperglycemic and hypoglycemic activities of Phyllanthus debilis aqueous plant extract in mice. Pharm Biol. 2009:47(3):260-5.

7. Chandrashekar KS, Joshi AB, Satyanarayana D, Pai P. Analgesic and antiinflammatory activities of Phyllanthus debilis. Whole Plant Pharmaceutical Biology. 2005:43(7):586-8.

8. Sureban SM, Subramaniam D, Rajendran P, Ramanujam RP, Dieckgraefe BK, Houchen CW, et al. Therapeutic effects of Phyllanthus species: induction of TNF-a-mediated apoptosis in HepG2 hepatocellular carcinoma cells. Am J Pharmacol Toxicol. 2006;1(4):70-6.

9. Mariappan P, Sundaramurthy K, Balasundaram J. Studies on phytochemical screening, total phenol content and antioxidant activity of root and shoot of Phyllanthus debilis and Phyllanthus virgatus. International Journal of Current Biotechnology. 2015;3(2):7-12.

10. Kumaran A, Karunakaran RJ. Antioxidant activity of polyphenols from Phyllanthus debilis Klein ex Willd. Journal of Natural Remedies. 2006;6:141-6.

11. Pharmacopia A. Department of ayurveda Colombo. Sri Lanka. 1975;1(3):71.

12. Soysa SSSBDP. Metabolism of caffeine: effects of chemical constituents of tea. University of Colombo UC (MED). 1996. p. 230.

13. Mitchell AE, Hong YJ, J. May C, Wright CA Bamforth CW. A Comparison of Polyvinylpolypyrrolidone (PVPP), Silica Xerogel and a Polyvinylpyrrolidone (PVP) - Silica Co-Product for Their Ability to Remove Polyphenols from Beer. J Inst of Brewing. 2005;111(1): 20-5.

14. Folin $\mathrm{O}$, Ciocalteu V. On tyrosine and tryptophane determinations in proteins. J Biol Chem. 1927;73:627-50.

15. Silva IK, Soysa P. Evaluation of phytochemical composition and antioxidant capacity of a decoction containing Adenanthera pavonina $\mathrm{L}$ and Thespesia populnea L. Pharmacogn Mag. 2011;7(27):193-9.

16. Adedapo AA, Jimoh FO, Afolayan AJ, Masika PJ. Antioxidant activities and phenolic contents of the methanol extracts of the stems of Acokantheraoppositifolia and Adeniagummifera. BMC Complement Altern Med. 2008;8:54.

17. Saeed N, Khan MR, Shabbir M. Antioxidant activity, total phenolic and total flavonoid contents of whole plant extracts Torilisleptophylla L. BMC Complement Altern Med. 2012;12:221.

18. Olugbami JO, Gbadegesin MA, Odunola OA. In vitro free radical scavenging and antioxidant properties of ethanol extract of Terminalia glaucescens. Pharmacognosy Research. 2015;7(1):49-56.

19. Gutteridge JM, Halliwell B. The deoxyribose assay: an assay both for "free" hydroxyl radical and for site-specific hydroxyl radical production. Biochem J. 1988;253(3):932-3

20. Fernando CD, Soysa P. Optimized enzymatic colorimetric assay for determination of hydrogen peroxide $\left(\mathrm{H}_{2} \mathrm{O}_{2}\right)$ scavenging activity of plant extracts. Methods X. 2015;2:283-91.

21. Mosmann T. Rapid colorimetric assay for cellular growth and survival: application to proliferation and cytotoxicity assays. J Immunol Meth. 1983; 65:55-63.

22. War AR, Paulraj MG, Ahmad T, et al. Mechanisms of plant defense against insect herbivores. Plant Signal Behav. 2012;7(10):1306-20.
23. Brunetti C, Ferdinando MD, Fini A, Pollastri S, Tattini M. Flavonoids as antioxidants and developmental regulators: relative significance in plants and humans. Int J Mol Sci. 2013;14(2):3540-55.

24. Kumar S, Pandey AK. Chemistry and biological activities of flavonoids: an overview. Sci World J. 2013. doi:10.1155/2013/162750.

25. He F, Pan QH, Shi Y, Duan CQ. Biosynthesis and genetic regulation of proanthocyanidins in plants. Molecules. 2008;13:2674-703.

26. Chandrashekar KS, Joshi AB, Satyanarayana D, Pai P. Phytochemical observation of whole plant of phyllanthus debilis klein ex willd. Anc Sci Life. 2005;25(1):39-41.

27. Gülçin I. $\mathrm{Fe}^{3+}-\mathrm{Fe}^{2+}$ transformation method: an important antioxidant assay. Methods Mol Biol. 2015;1208:233-46.

28. Ahmed D, Khan MM, Saeed R. Comparative analysis of phenolics, flavonoids, and antioxidant and antibacterial potential of methanolic, hexanic and aqueous extracts from Adiantum caudatum leaves. Antioxidants. 2015;4(2): 394-409.

29. Lipinski B. Hydroxyl radical and its scavengers in health and disease Oxidative Med Cell Longev. 2011. doi:10.1155/2011/809696.

30. Pacher P, Beckman JS, Liaudet L. Nitric oxide and peroxynitrite in health and disease. Physiol Rev. 2007:87(1):315-424.

31. Lennicke C, Rahn J, Lichtenfels R, Wessjohann LA, Seliger B. Hydrogen peroxide - production, fate and role in redox signaling of tumor cells. Cell Communication and Signaling. 2015;13:39. doi:10.1186/s12964-015-0118-6.

32. Gorinstein S, Weisz M, Zemser M, Tilis K, Stiller A, Flam I, et al. Spectroscopic analysis of polyphenols in white wines. Journal of fermentation and bioenoineering. 1993:75(2):115-20.

33. Kumaran A, Karunakaran RJ. In vitro antioxidant activities of methanol extracts of five Phyllanthus species from India. LWT- Food Science and Technology. 2007:40(2):344-52.

34. Verza SG, Pavei C, Ortega GG. Study of the Specificity of Cross-Povidone (PVPP) as binding agent in the quantification of polyphenolic compounds. J Braz Chem Soc. 2008;19(8):1627-33.

35. Elmore S. A review of programmed cell death. Toxicol Pathol. 2007;35(4): 495-516.

36. Anokwuru CP, Sinisi A, Samie A, Taglialatela-Scafati O. Antibacterial and antioxidant constituents of Acalypha wilkesiana. Nat Prod Res. 2015;29(12): 1180-3.

37. Li J, Wang S, Yin J, Pan L. Geraniin induces apoptotic cell death in human lung adenocarcinoma A549 cells in vitro and in vivo. Can J Physiol Pharmacol. 2013;91(12):1016-24.

38. Mao X, Wu LF, Guo HL, Chen WJ, Cui YP, Qi Q, et al. The genus Phyllanthus: an ethnopharmacological, phytochemical, and pharmacological review. Evidence-Based Complementary and Alternative Medicine. 2016. doi:10. 1155/2016/7584952.

39. Paolini A, Crti V, Pasi F, Mazzini G, Nano R, Capelli E. Gallic acid exerts a protective or an anti-proliferative effect on glioma T98G cells via dosedependent epigenetic regulation mediated by miRNAs. Int J Oncol. 2015; 46(4):1491-7.

40. Chuang CY, Liu HC, Wu LC, Chen CY, Chang JT, Hsu SL. Gallic acid induces apoptosis of lung fibroblasts via a reactive oxygen species-dependent ataxia telangiectasia mutated-p53 activation pathway. J Agric Food Chem. 2010; 58(5):2943-51.

41. Parvathaneni M, Battu GR, Gray Al, Gummalla P. Investigation of anticancer potential of hypophyllanthin and phyllanthin against breast cancer by in vitro and in vivo methods. Asian Pac J Trop Dis. 2014:4 Suppl 1:71-6.

\section{Submit your next manuscript to BioMed Central and we will help you at every step:}

- We accept pre-submission inquiries

- Our selector tool helps you to find the most relevant journal

- We provide round the clock customer support

- Convenient online submission

- Thorough peer review

- Inclusion in PubMed and all major indexing services

- Maximum visibility for your research

Submit your manuscript at www.biomedcentral.com/submit 